\title{
Study of Physiological Properties of Salad Oils Used in Healthful and Dietary Meals
}

\author{
Vasilenko V.N. \\ Dean of Technological Faculty \\ Voronezh State University of Engineering \\ Voronezh, Russia \\ e-mail: vvn1977@mail.ru \\ Dragan I.V \\ Associate Professor \\ Voronezh State University of Engineering \\ Voronezh, Russia
}

\author{
Frolova L.N. \\ Associate Professor \\ Voronezh State University of Engineering \\ Voronezh, Russia \\ e-mail: fln-84@mail.ru \\ Mikhaylova N.A. \\ Head of Production Laboratory \\ DECO MINERALS \\ Voronezh, Russia \\ e-mail:mna8686@mail.ru
}

\begin{abstract}
Human life quality and activity are greatly influenced by nutrition since unhealthy diet can entail chronic diseases. Therefore, the authors of the paper make an attempt to dwell on some kinds of food products that are consumed by people on a daily basis, namely oils. The paper deals with the functional food that performs the energy function, as well as improves human being health. The authors of the paper put emphasis on fatty products, particularly vegetable oils that are not paid enough attention in the scientific literature. The polyunsaturated fatty acid content, physical and chemical parameters of vegetable oils available on the Russian market were studied. Two samples of salad oils, their biochemical parameters, composition and fatty acid content were characterised using GOST standards. The experiments were performed using white male rats, which were fed with salad oil. These experiments allowed assessing in the rats' bodies the amount of sulfur, an increase of which can lead to the increase in relative vital mass coefficients (heart, kidneys, liver, spleen) and demonstrate a certain negative impact on the organism of the rats, consuming salad oil containing sulfur.
\end{abstract}

Keywords - composition, salad oil, vegetable oil, physiological properties

\section{INTRODUCTION}

At present, Russia and other world countries pay much attention to healthy lifestyle and healthy nutrition since it is proved that unhealthy diet is one of chronic disease risk factors $[6,9,10,24,28]$.

Functional food is quite often perceived by consumers as medical and is opposed to traditional food. However, these are food products intended for systematic in dietary intake by all age groups of the healthy population. Functional food is the food that performs not only the energy function supplying us with energy and delivering plastic material for body structure, but it is also the food that improves our health and condition, reduces risk of various diseases. Such food products have a great impact on one or several body functions or its certain organs and systems [11-22, 32].

The simplest and economically viable way of creating fatty products satisfying the above requirements is mixing (blending) of oils having different composition before they are included into the ingredients of any product. Among food items produced by oil and fat industry the emulsion products (spread, margarine, sauce) are the most suitable for transformation. They are supplemented with special ingredients for giving them functional properties, while not enough attention is paid to the value of vegetable oils forming the formula for these products $[23,27,30]$.

There are some domestic and foreign studies on this matter. Skoryukin A.N. suggests the technology to receive and apply blended fatty products with optimal polyunsaturated fatty acid content. The polyunsaturated fatty acid content and physical and chemical parameters of vegetable oils available on the Russian market was studied: refined (sunflower, soya, rape, corn, cameline) and unrefined oils (sunflower, flaxseed, cameline and wheat germ oil). The oxidation of blended oils with the use of advanced technique was studied. There is an assumption on the possibility of increasing the efficiency of vitamin $\mathrm{E}$ and $\mathrm{B}-$ Carotene due to their increased physiological demand. Kopylov M.V. developed a cold pressing technology of vegetable oil-bearing crops with subsequent blending. He justified the change of rheological characteristics of obtained blends of vegetable oils. Shematonov D.V. developed the functional technology of creamy-vegetable spread, proposed the methodology of receiving vegetable oil mixes characterized by balanced fatty acid content. The methodology is based on the principles of balancing the fatty acid content of two- and three-component mixes of vegetable oils satisfying modern physiological requirements. Savelyev I.D. studied the technology of functional creamy-vegetable spread using complex emulsifiers. He managed to develop models describing the dependence of organoleptic and physicalchemical parameters of spread on fat mass fraction of a final 
product and on the content of emulsifier and liquid vegetable oil. However, these studies do not fully reflect the influence of received products on a human body and do not demonstrate health properties of received blends [24-26, 28, 29, 31-33].

Thus, the creation of balanced recipes of fatty products having increased nutrition value with improved fatty acid content, medical effect and enriched with lipid soluble vitamins may be considered as an important aspect of modern nutrition, which fosters the development of some interrelated branches of oil and fat industry. Modern food production reached a new step of its development when the food program shall satisfy not only the needs of the population for certain food products, but also ensure their basic nutrient balance. One of such products is salad oil [7, 8, 21].

In recent years the scholars may more attention to physiological properties of vegetable oils. The postmortem and toxicological study on laboratory animals receiving highly erucidic oils revealed some myocardial necrotic changes, decreased activity of liver glucose 6-phosphatase and adenyl cyclase during lipid myocardial infiltration, deceleration of adenosine triphosphate synthesis, skeletal muscles obesity, kidneys disorder, liver cirrhosis [2, 5, 27].

It shall be noted that with the introduction of non-erucidic oils to diets of animal the above specified problems still remained, but were less expressed. Hence, not only erucidic acid, but also other oil ingredients, such as sulfur-containing substances, have the negative impact on the body. They cause mucous membrane irritation of digestive tract, airways and thyroid gland disorder [3, 4, 32].

The purpose of the study is to create salad oils on the basis of composition of rape, cameline, safflower and coriander oil having the health-promoting effect and to study the physiological properties of final products on laboratory animals.

\section{MATERIALS AND METHODS}

Two samples of salad oils were studied: I - salad oil made of rape (GOST 31759-2012), safflower (GOST 12096-76) and coriander oil (GOST 31791-2017), II - salad oil made of cameline (GOST 10113-62), safflower (GOST 12096-76) and coriander oil (GOST 31791-2017), which make it possible to obtain specific fatty acids and other lipids not typical for traditional vegetable oils or, if present, only in small quantities. The study focused on organoleptic, physical and chemical properties, as well as safety indicators of initial vegetable oils as components for the salad oil. The below state standards (GOSTs) and methods were used to assess the quality of vegetable oils.

Color, flavor, transparency level and a ratio of phosphoruscontaining substances were defined in compliance with GOST 5472-50. Qualitative soap test was carried out according to GOST 5480-59. Moisture and volatile substances were defined according to GOST 11812-66. The peroxide number was defined in vegetable oils via titration method in accordance with GOST P 51487-99. The acid number was determined through titration of a fat sample with potassium hydroxide solution. Phenolphthalein served the indicator (GOST P 52110-2003). The color value was defined on the basis of GOST 5477-93 using the Lovibond PFX 995 device. The measurement range made $420-710$ nanometers. The results were obtained in iodine units and according to Lovibond RYBN colour scale (red, blue, yellow, neutral). The iodine value in samples was defined in accordance with GOST 5475-69; soap factor in samples - in accordance with GOST 5480-59. The mass fraction of tocopherol was defined by MU 08-47/184 (FR. 1.31.2005.01810) via the HELC method.

Via the modified technique the fatty acids content of oils was placed on a Khromatek-Kristall gas chromatograph. The flame ionization detector was used in the study. Sample preparation and determination of fatty acid content was carried out in accordance with GOST 51483-99. The amino-acid content was defined via ion-exchange chromatography on AAA-881 amino analyzer.

All experiments with white male rats were carried out at V.M. Gorbatov Federal Research Center for Food SystemsRAS taking into account the existing ethical standards and rules in strict compliance with the research protocol and current legal requirements. Biological studies were conducted in two groups of white male rats with initial mass $(68 \pm 1.9) \mathrm{g}$ (16 animals in each group). The experimental animals were kept on a balanced diet that included the following caloric content: $18 \%$ protein (casein), 62\% carbohydrates (potato starch) and $20 \%$ fat - studied samples of salad oil. Besides, the diets included all necessary mineral substances and the complex water- and lipid soluble vitamins. The specified diets were fed to experimental animals within 10 weeks. During this period, we observed the body height, development and the general condition of animals.

TABLE I. CHARACTERISTICS OF BIOCHEMICAL COMPOSITION OF SALAD OILS

\begin{tabular}{|c|c|c|}
\hline Parameter & Test sample I & Test sample II \\
\hline Acid value, $\mathrm{mg} \mathrm{KOH} / \mathrm{g}$ & 1.19 & 1.28 \\
\hline Iodine value, $\mathrm{g} \mathrm{J}_{2} / 100 \mathrm{~g}$ & 112 & 128 \\
\hline Color value, $\mathrm{mg} \mathrm{J}_{2}$ & 28.1 & 28.9 \\
\hline $\begin{array}{c}\text { Peroxide number, } \mathrm{mmol} \text { of active } \\
\text { oxygen, } \mathrm{kg}\end{array}$ & 2.46 & 2.67 \\
\hline Wax mass fraction, $\%$ & 0.15 & 0.12 \\
\hline Saponification value, $\mathrm{mg} \mathrm{KOH} / \mathrm{g}$ & 172 & 178 \\
\hline Moisture and volatile content, $\%$ & 1.15 & 0.28 \\
\hline $\begin{array}{c}\text { Mass fraction of unsaponification } \\
\text { matters, } \%\end{array}$ & 0.21 & 303.7 \\
\hline Tocopherol content, $\mathrm{mg} / \mathrm{kg}:$ & & 119.3 \\
\hline$\alpha$-tocopherol & 438.4 & 289.9 \\
\hline$\beta$-tocopherol & 217.2 & 3.19 \\
\hline$\gamma$-tocopherol & 303.3 & \\
\hline Sulfur content, $\mathrm{mg} / \mathrm{kg}$ & 2.10 & \\
\hline
\end{tabular}


TABLE II. FATTY ACID CONTENT IN THE STUDIED SAMPLES OF SALAD OILS

\begin{tabular}{|l|c|c|c|c|c|c|c|}
\hline \multirow{2}{*}{ No. of sample salad oil } & \multicolumn{9}{|c|}{ Fatty acids } \\
\cline { 2 - 8 } & Palmitic acid & Stearic acid & Oleic acid & Linoleic acid & Linolenoic acid & Gadoleic acid & Erucidic acid \\
\hline Test sample I & 7.15 & 2.28 & 23.68 & 47.15 & 4.68 & 8.32 & 0.15 \\
\hline Test sample II & 6.62 & 2.01 & 23.25 & 42.36 & 3.97 & 9.25 & 0.09 \\
\hline
\end{tabular}

TABLE III. BIOLOGICAL PARAMETERS

\begin{tabular}{|l|c|c|}
\hline \multicolumn{1}{|c|}{ Parameter } & \multicolumn{2}{c|}{ Salad oil } \\
\cline { 2 - 3 } & First sample & Second sample \\
\hline Rat body weight, g, M $\pm \mathrm{m}$ & $263 \pm 8$ & $273 \pm 8$ \\
\hline Energy efficiency of a diet, kcal/g of body weight gain & 20.7 & 20.1 \\
\hline Content in blood serum, mg \%, M \pm m: & & $273 \pm 14$ \\
Total lipids & $259 \pm 10$ & $166 \pm 11$ \\
Beta-lipoproteins & $185 \pm 11$ & $82 \pm 4$ \\
Cholesterol & $62 \pm 5$ & \\
\hline Mass fraction ratio, M \pm m: & $32.7 \pm 1.0$ \\
liver & $31.4 \pm 1.0$ & $6.9 \pm 0.3$ \\
kidneys & $6.8 \pm 0.3$ & $2.4 \pm 0.3$ \\
spleen & $2.2 \pm 0.1$ & $4.1 \pm 0.1$ \\
heart & $3.6 \pm 0.2$ & 34.2 \\
\hline Chemical composition of rat organs and tissues: & & 38.0 \\
total lipids, g & 27.0 & 43.0 \\
total lipids, \% (of dry matter) & 32.0 & 47.8 \\
proteins, g & 46.7 & 7.7 \\
proteins, \% & 55.6 & 8.5 \\
mineral substances, g & 7.7 & 1.25 \\
\% of dry matter & 9.2 & 24.3 \\
Protein-lipid ratio & 1.72 & 1.42 \\
Lipid content in rat liver, \% of liver dry matter & 21.9 & \\
FEM & 1.64 & \\
\hline
\end{tabular}

The results of the study were processed by parametric methods of variation statistics using epy Student's t-test for unrelated populations. The arithmetic average $(M)$, mean square deviation $(\sigma)$, variation coefficient $(V)$, mean arithmetic average error $(m)$ were defined to check the statistical significance of two samples at significance level $\mathrm{p}<0.05$

\section{RESULTS AND DISCUSSION}

Biochemical parameters and fatty acid content of two samples of salad oils were studied (Tab. 1,2).

It is found that both groups of rats had a similar palatability ratio of diets, as well as similar body weight gain and hence, almost similar energy efficiency of a diet (Tab. 3).

Upon termination of biological observations, 10 rats were selected from each group to define the lipid fraction of blood serum. Quite similar content of total lipids and betalipoproteins was noted. The rats of the II group had higher content of total cholesterol in the blood serum. The differences between groups regarding this parameter were statistically reliable (Tab. 3).

The data on chemical composition of organs and tissues of animals showed that the samples of salad oil had a different influence on the organism of rats. Thus, the rats of the I group accumulated less depot fat and total lipids. The protein content was higher. As a result, they had high protein-lipid ratio 1.72. Such protein-lipid ratio is typical for animals consuming liquid vegetable oils. The rats of the II group had lower ratio of accumulated basic materials. They had increased lipid content and decreased accumulated protein content thus leading to sharp reduction of protein-lipid ratio (to 1.25 ). This fact shall be considered as the degradation factor of biological properties of the $2^{\text {nd }}$ sample of salad oil. As for lipid content in a liver, it shall be noted that it was increased for both groups of rats (Tab. 3).

The postmortem examination of organs and tissues of rats demonstrated minor macroscopic changes of digestive tract mucosae and more significant changes resulting in fatty liver of both experimental groups. The study of relative coefficients of vital mass (heart, kidneys, liver, spleen) showed the tendency towards their increase for rats of the II group, and the relative coefficient of the heart mass was even characterized by statistically valid increase $(\mathrm{P}<0.05)$, which demonstrates a certain negative impact of the $2^{\text {nd }}$ sample of the studied salad oil on the organism of animals.

\section{CONCLUSIONS}

The development of compositions of salad oils not containing erucidic acid allows improving and balancing the fatty acid content in relation to polyunsaturated fatty acid $\omega-3$ and $\omega-6$, as well as those having a health-promoting effect. The animals did not have considerable differences in metabolism of fatty acids when fed with a diet of the $1^{\text {st }}$ and the $2^{\text {nd }}$ sample of salad oils, which is confirmed by FEM value (1.64 and 1.42 respectively). However, increase in sulfur content of the studied samples from 2.10 to $3.19 \mathrm{mg} / \mathrm{kg}$ leads 
to the increase in relative vital mass coefficients (heart, kidneys, liver, spleen), which demonstrates a certain negative impact on the organism of animals consuming salad oil containing $3.19 \mathrm{mg} / \mathrm{kg}$ of sulfur.

\section{References}

[1] S. Burt, "Essential oils: their antibacterial properties and potential applications in foods-a review", International journal of food microbiology, 2004, Vol. 94, No. 3, pp. 223-253.

[2] S. K. Lo et al, "Diacylglycerol oil - properties, processes and products: a review", Food and Bioprocess Technology, 2008, Vol. 1, No. 3, p. 223.

[3] G. Brufau, M. A.Canela, M. Rafecas, "Phytosterols: physiologic and metabolic aspects related to cholesterol-lowering properties",/Nutrition Research, 2008, Vol. 28, No. 4, pp. 217-225.

[4] G. Aruna, V. Baskaran, "Comparative study on the levels of carotenoids lutein, zeaxanthin and $\beta$-carotene in Indian spices of nutritional and medicinal importance", Food chemistry, 2010, Vol. 123, No. 2, pp. 404409

[5] L. A. Puente et al, "Physalis peruviana Linnaeus, the multiple properties of a highly functional fruit: A review", Food Research International, 2011, Vol. 44, No. 7, pp. 1733-1740.

[6] A. Drewnowski, "Obesity and the food environment: dietary energy density and diet costs", American journal of preventive medicine, 2004 Vol. 27, No. 3, pp. 154-162.

[7] V.N. Vasilenko, L.N. Frolova, N.A. Mikhailova, K.Yu. Rusina, D.A. Tarkaeva, "The creation of energy efficient equipment for processing oilseeds", Russian Engineering Research, 2017, Vol. 37, No. 4, pp. 330331

[8] A. Kairbayeva, V. Vasilenko, S. Dzhinguilbayev, L. Baibolova, L. Frolova, "Development of the mathematical model for the process of oil raw materials pressing", Journal of Engineering and Applied ,2017, Vol. 12, Issue: 26 , pp. 7836-7842.

[9] M.V. Kubekina, V.A. Myasoyedov, V.P. Karagodin, A.N. Orekhov, "Food phospholipids: influence on lipid exchange and cardiovascular risk factors", Problems of Nutrition, Vol. 86, No. 3, 2017, pp. 6-18.

[10] N.S. Rodionova, V.A. Isaev, A.B. Vishnyakov, E.S. Popov, N.V. Safonova, S.A.Storublevtsev, "Influence of oil and flour from wheat germ cake on lipid exchange of university students and teachers", Problems of Nutrition, Vol. 85, No. 6, 2016, pp. 57-63.

[11] E. Antonini et al, "Phenolic compounds and quality parameters of family farming versus protected designation of origin (PDO) extra-virgin olive oils", Journal of Food Composition and Analysis, vol. 43, pp. 75-81, 2015.

[12] G.K. Beauchamp et al, "Ibuprofen-like activity in extra-virgin olive oil", Nature, vol. 437 (7055), pp. 45-46, 2005.

[13] N. Caporaso et al, "Nutritional quality assessment of extra virgin olive oil from the Italian retail market: Do natural antioxidants satisfy EFSA health claims?", Journal of Food Composition and Analysis, vol. 40, pp. 154-162, 2015.

[14] G. Ciafardini, B.A. Zullo, G. Peca, "Presence of microorganisms in flavoured extra-virgin olive oil", Annals of Microbiology, vol. 54 (2), pp. 161-168, 2004.

[15] S. Cicerale, L.J. Lucas, R.S.J. Keast, "Antimicrobial, antioxidant and anti-inflammatory phenolic activities in extra virgin olive oil", Current Opinion in Biotechnology, vol. 23 (2), pp. 129-135, 2012.

[16] A. Cusimano et al, "Oleocanthal exerts antitumor effects on human liver and colon cancer cells through ROS generation", International Journal of Oncology, vol. 51 (2), pp. 533-544, 2017.
[17] M. Czerwińska, A.K. Kiss, M. Naruszewicz, "A comparison of antioxidant activities of oleuropein and its dialdehydic derivative from olive oil, oleacein”, Food Chemistry, vol. 131 (3), pp. 940-947, 2012.

[18] M.S. Deshpande, V.B. Rale, J.M. Lynch, "Aureobasidium pullulans in applied microbiology: A status report", Enzyme and Microbial Technology, vol. 14 (7), pp. 514-527, 1992.

[19] R.Fabiani, Anti-cancer properties of olive oil secoiridoid phenols: A systematic review of: In vivo studies Food and Function, vol. 7 (10), pp. 4145-4159, 2016

[20] C. Gostinčar et al,. "Genome sequencing of four Aureobasidium pullulans varieties: Biotechnological potential, stress tolerance, and description of new species", BMC Genomics, vol. 15 (1), Art. 549, 2014.

[21] A. Koidis, E. Triantafillou, D. Boskou, "Endogenous microflora in turbid virgin olive oils and the physicochemical characteristics of these oils", European Journal of Lipid Science and Technology, vol. 110 (2), pp. 164-171, 2008.

[22] D. Krichene, M.D. Salvador, G. Fregapane, "Stability of Virgin Olive Oil Phenolic Compounds during Long-Term Storage (18 Months) at Temperatures of $5-50^{\circ} \mathrm{C} "$, Journal of Agricultural and Food Chemistry, vol. 63 (30), pp. 6779-6786, 2015

[23] M. Servili et al, "Health and sensory properties of virgin olive oil hydrophilic phenols: Agronomic and technological aspects of production that affect their occurrence in the oil", Journal of Chromatography A, vol. 1054 (1-2), pp. 113-127, 2004.

[24] F. Angerosa, R. Mostallino, C. Basti, R. Vito, "Influence of malaxation temperature and time on the quality of virgin olive oils", Food Chemistry, vol. 72 (1), pp. 19-28, 2001.

[25] F. Angerosa et al, "Volatile compounds in virgin olive oil: Occurrence and their relationship with the quality ", Journal of Chromatography A, vol.1054 (1-2), pp. 17-31, 2004

[26] F.Espínola et al, "Improved extraction of virgin olive oil using calcium carbonate as coadjuvant extractant", Journal of Food Engineering, vol. 92 (1), pp. 112-118, 2009

[27] C.M. Kalua et al, "Olive oil volatile compounds, flavour development and quality: A critical review", Food Chemistry, vol. 100 (1), pp. 273 286, 2007.

[28] C.M. Kalua et al, "Changes in volatile and phenolic compounds with malaxation time and temperature during virgin olive oil production", Journal of Agricultural and Food Chemistry, vol. 54 (20), pp. 76417651,2006

[29] G. Luna et al, "Characterisation of 39 varietal virgin olive oils by their volatile compositions", Food Chemistry, vol. 98 (2), pp. 243-252, 2006

[30] M. Servili et al, "The use of biotechnology means during oil mechanical extraction process: Relationship with sensory and nutritional parameters of virgin olive oil quality", Acta Horticulturae, vol. 586, pp. 557-560, 2002

[31] P. Reboredo-Rodríguez et al, "Improvements in the malaxation process to enhance the aroma quality of extra virgin olive oils", Food Chemistry, vol. 158 , pp. 534-545, 2014

[32] M. Servili et al, "Health and sensory properties of virgin olive oil hydrophilic phenols: Agronomic and technological aspects of production that affect their occurrence in the oil", Journal of Chromatography A, vol. 1054 (1-2), pp. 113-127, 2004.

[33] S.A. Vekiari, A. Koutsaftakis, "The effect of different processing stages of olive fruit on the extracted olive oil polyphenol content", Grasas y Aceites, vol. 53 (3), pp. 304-308, 2002. 